\title{
Review of Methods and Tools for Intellectual Property Analysis of Public Sector Entities ${ }^{1}$
}

\section{Elena Khomenko}

$\mathrm{PhD}$ in economics, Associate Professor

ORCID

E-mail: xomenko@corp.nstu.ru

Novosibirsk State Technical University, Faculty of Business, Novosibirsk, Russiaa

Journal of Corporate Finance Research, Vol. 14, No. 3, pp. 63-89 (2020)

DOI: https://doi.org/10.17323/j.jcfr.2073-0438.14.3.2020.63-89

Received 13 April 2020 | Peer-reviewed 15 May 2020 | Accepted 25 May 2020

1 Исследование выполнено при финансовой поддержке РФФИ в рамках научного проекта № 19-11050388 (The reported study was funded by RFBR, project number № 19-110-50388). 


\section{Review of Methods and Tools for Intellectual Property Analysis of Public Sector Entities}

\section{Abstract}

The low efficiency of intellectual property (IP) in the public sector in our current economic environment is largely due to the insufficient development of the prevailing accounting and analytical system. Analytical methods, and the information basis of their application, are the core of this system. The formation of an accounting and analytical system consistent with the development priorities of public sector entities requires special research.

This article provides a review of the methods and tools of analysis used by Russian and foreign scientists in the field of IP. Our research sample comprises 52 foreign and 39 Russian sources. Through a detailed textual analysis process, we systematise the existing methods used in the analyses of certain aspects of intellectual activity, and assess the information disclosure therein. Our evaluation is targeted towards identifying prospects for harmonising Russian and international approaches, and provide the groundwork for the improvement of accounting and analytical support for IP management in the public sector.

Our results reveal possibilities for expanding the system of IP analysis methods for solving problems in the field of the IP economics and management on the basis of patent analytics. We also collate and classify patent analytics methods, and identify existing methodological problems at the macro- and microeconomic levels. Analytical methods are grouped in accordance with three stages of the reciprocal model of IP accounting and analysis in the public sector, developed within the framework of a novel theoretical and methodological approach.

In conclusion, we illustrate the potential for applying the methods of nonlinear dynamics and the dynamic theory of innovation (re: patent information) to determine the trajectories of public sector entity development concerning levels of information disclosure. We also identify areas for follow up research revealed through our analysis.

Keywords: intellectual property, intangible assets, public sector, patent analytics, information disclosure

JEL classification: O34, O32, H83, M41, G32 


\section{Introduction}

Issues around intellectual property (IP) analysis and the efficiency of such analysis have grown in relevance in recent years. This is especially the case in the public sector, where global development trends are related to the strengthening of the role of public sector entities in the area of science and innovation. As such, active distribution of scientific knowledge throughout society, and in particular to industrial entities, assumes an ever-greater level of importance in the assessment of of public sector entity performance. However, theoretical and methodological research and methodological guides dedicated to IP analysis are currently not sophisticated enough (можно оставить так) and offer no opportunity to develop reasoned recommendations for improving efficiency or choice of the best ways to commercialise IP. This situation has been described in a number of research papers published over recent years.

We analyse various publications on IP management, patent analytic investigations, and the disclosure of knowledge capital and intangible assets, in aggregate comprising 900 scientific articles. Our results indicate that investigations in these areas focused mainly on patenting, including patentability evaluation and choice of legal protection types [1]. Scientists pay special attention to patenting and licensing of university research results performed by Technology Transfer Offices (TTOs) founded in American universities after the passing of the Bayh-Dole Act of 1980 [2]. University-industry research cooperation, efficient collaboration of public and commercial entities [3], measurement of the innovation potential of research and development centers in the public and commercial sector [4], and the development of effective technology transfer models each represent multifaceted and significant areas of relevance.

It should be noted that the majority of scientific papers relevant to this area are focused on solving certain research issues rather than systematising methods and tools. Special studies on analysis of applied methods were dedicated only to patent analytics [6; 7], while the system of economic methods applied to solve problems of effective commercialisation in IP management has been rather neglected in earlier research.

We contend that databases represent a resource of primary importance for solving economic and management problems, and applying corresponding analytical methods. In this regard, our study is especially focused on the disclosure of information on IP and intangible assets, and assessment methods of public sector entities' transparency. The published scientific papers we reviewed lack such research in terms of public sector focus. Thus, F. Castilla-Polo and D. Gallardo-Vázquez, who performed a critical review of publications on the disclosure of intangible assets information, pointed out that the majority of research papers evaluated large public companies, while the number of small business and public sector entities analysed was insufficient [8]. F. Castilla-Polo and C. Ruiz-Rodriguez, who published 74 academic papers ap- plying content analysis methodology to study disclosure established that in $61 \%$ of research papers public companies' data was used [9]. In the paper by B. Cuozzo, J. Dumay, M. Palmaccio and R. Lombardi - which analysed 246 scientific papers on intellectual capital disclosure just $5 \%$ of papers were related to the study of the public sector [10].

It should be noted that public universities occupy a special position among public sector entities, which is borne out in the existing research. The problems of the analysis and assessment of efficiency of public universities' IP utilisation are characterised by a number of distinctive features which are of importance for our research, which will be detailed below.

When we summarised the research results from recent years we failed to find a significant number of survey papers published by Russian authors on this theme. Additionally, there are very few Russian scientists' papers cited in the survey research of foreign authors. Against this background, we propose that in our research Russian publications should be studied separately in order to find out possible similarities and differences in approaches and methods of IP analysis. We also propose to define the prospects of integration and harmonisation of research methodologies.

Considering the background of the development of unified theoretical and methodological justifications of accounting and analytical support of IP management in the public sphere, we assume that IP analysis tools should be improved. This motivation provides for the creation of a database to be used for taking reasoned management decisions. So, one of the objectives of this paper is the adjustment of the methods that are systematised in the survey research (in accordance with the stages of the reciprocal model of IP accounting and analysis in the public sector, which we outline). The model comprises procedures of identification and commercialisation of IP, and is described in detail in papers $[11 ; 12])$.

This paper consists of the following sections. The section titled 'Research Methodology' outlines research issues and describes the core principles of preparing the studied research selection for analysis. In the section 'Research Results' we answer the raised scientific issues. 'Results Discussion' deals with the prospects of using the results of the present research for the purposes of IP management in the public sector. This is justified on the basis of a new methodological approach, developed by the author and presented herein. To close, 'Summary and Conclusions' are articulated in the final section of the paper.

\section{Research Methodology}

We defined the research questions (RQs) stated below on the basis of up-to-date trends of development of the analysed topic, the displacement of vectors related to the topic and to applied research methods, and with a consideration of the lack of papers on analysis of public sector entities' operations. 
RQ1. Which methods are used in IP analysis of public sector entities, and are there any differences in the methods applied by foreign and Russian scientists?

RQ2. What are the main objectives and analytical methods of disclosure of IP and intangible assets by public sector entities?

We searched for scientific papers in the Web of Science and Google Scholar databases using all available sources. We used the following query fields: 'Title', 'Abstract', and the 'Key Words' used were "intellectual property" and "intangible assets". The search results were limited by the 'AND' filter and the terms "public sector", "universities", "educational institutions" in order to select the researches related to the public sector. The terms "patent analytics" and "disclosure" were applied in order to select certain segments of the sampling.

In order to analyse the Russian segment using the same terms, we made a sampling of the most relevant academic papers, monographs, and educational publications by Russian scientists taken from the Elibrary database, the electronic library system Znanium, the electronic catalogues of the Russian State Library and the State Public Scientific Technological Library of the Siberian Branch of the Russian Academy of Sciences.

The search did not comprise the term "goodwill" related in its meaning to our topic, which covers the issues of intangible assets and IP management. This is because it mainly pertains to the commercial sector, while in our research the primary focus is on the public sector entities. Analysing the abstracts and key conclusions of the papers included in the sampling, we selected 10 review papers where the research was not focused on regional issues or certain sciences (e.g. medicine, physics etc.) and which were of maximum relevantce the scientific issues raised. Moreover, we chose papers written in the past five years since 2016, as survey researches of recent years comprise the most relevant publications up to the present day. We selected themed published papers, which analysed IP from a variety of perspectives, on the basis of the content of abstracts and key research results. The most often quoted papers were preferred.

\section{Research Results \\ Current Status of Research on Public Sector Entities' IP, based on existing Reviews}

The papers on innovation management, management of IP activity results and intellectual capital account for the widest range of issues. Analysis of academic papers conducted by M. Holgersson and S. van Santen, which comprised 12 review papers and over 400 articles dedicated to certain management areas, revealed that this topic in general has been on the rise since the 2000s, showing a substantial increase in the number of published papers. In this author's opinion, a significant revelation is the fact that most of the research is related to patent rights items (in particular, inventions) and that substantially smaller attention is paid to other IP items and issues of alignment of patent and business strategy in general in the field of strategic management [1]. As such, we pay particular attention to the special issue of the International Journal of Industrial Organization (2003), titled “The Economics of Intellectual Property at Universities" which deals mainly with the issues of policy-making and some economic and IP management issues. Topics covered include licensing and university-industry collaboration, which are within the competence of TTOs.

M. Holgersson and L. Aaboen, who conducted a survey of 108 literature sources with respect to performance of TTOs founded in universities to commercialise development results established that as a rule, existing research represented a simplistic approach to management of IP results. The predominant approach is based upon recommendations concerning the choice of legal protection of items, the description of the protected contents of engineering solutions, and the determination of a patent holder. Within this approach, which we name the "appropriation model", the key performance indicators are the quantity of patents, licenses, and spin-offs a university has. In the authors' opinion, in a more efficient "utilisation model", it is necessary to emphasise how TTOs facilitate access to universities' protected research results, how awareness of concerned parties of the universities' research activity is facilitated, how the provision of continuity of the innovation process is managed, and how partnering with the business community is managed [2].

C. Mascarenhas, J.J. Ferreira, and C. Marques also write of the importance of partnering with private companies, which should be arranged by TTOs. Their bibliometric analysis of 294 papers (which consider innovation strategies based on cooperation of universities with businesses) showed that companies are taking an increased interest in scientific cooperation with universities. The thematic clusters of the published papers which the authors have selected are associated with various focuses of such cooperation [3].

Apart from the problems solved by TTOs, P. Maresova, R. Stemberkova and O. Fadeyi considered existing technology transfer models applied in various countries and selected 22 relevant sources after performing a systematic literature review [5]. The authors established that generally accepted or 'most efficient' standard models do not exist. The models become more complicated as the commercialisation process complexifies, and institutional and other conditions of innovation process implementation change. At the same time, issues of IP management remain the central issues in various technology transfer models.

The research by I. Buonomo, P. Benevene, B. Barbieri and M. Cortini comprises a review of nine published papers on a rather narrow topic related to the influence of intangible assets on the performance of non-commercial organisations. In spite of the controversial approach applied by the authors when they consider various intel- 
lectual capital components (including human, relational and structural capital) as intangible assets, the discussion opened up by the authors concerning the parameters characterising the performance of non-commercial organisations is noteworthy. In that study, the relation between intangible assets and performance manifests itself in the fact that the use of intangible assets allows non-commercial organisations to carry out the core activities in the circumstances of government financing decrease and to withstand competition for additional funding sources with other non-commercial organisations [13].

Along with a performance assessment, the most important line of research is the measurement of innovation potential. Within this strand of research M. Yaghoubi, E. Teymourzadeh, M. Bahadori and F. Ghardashi made an extensive systematic review comprising 200 published papers which enabled them to develop a conceptual model of such measurements [4].

M. Holgersson and L. Aaboen emphasise that in the digitalisation environment, the importance of manufacturing secrets, copyright, and design inventions increases. Such items are often a "digital addition" to technology protected as inventions [2]. Information technology penetrates patent analytics more and more. A survey research by $\mathrm{L}$. Aristodemou and F. Tietze comprising 57 papers on this topic revealed an increasing number of cases of applying artificial intelligence, machine learning methods and deep learning technology when arrays of patent information were processed. Besides this, the authors defined four key fields of application of patent-analytical studies. They are: knowledge management (including classification and patent quality evaluation), technology management (revealing technology trends and forecast of development of certain technology areas), IP economic value (including the issues of high-tech companies' performance, patent value estimation and defining the amount of loss inflicted by patent infringements, as well as macroeconomic forecast issues), data management (including mainly patent digitising, provisioning of patent information databases and improvement of searching algorithms) [6].

Thus, the survey papers of recent years cover a wide range of published research which considers management in innovations, technology transfer including the role of universities in the processes of intellectual activity results' commercialisation, scientific potential evaluation and research output. The authors solve particular research problems in the above fields. However, in order to make a complete picture of the system of methods applied in IP analysis for solving various problems, it is necessary to conduct a separate survey research, the main purpose of which is systematising the methods applied by the authors instead of selecting topics for research. In its turn, methods systematisation will allow to reveal the problems related to the building of the database necessary for use of corresponding analytical tools, and this requires further study of disclosure issues. Additionally, in the existing research, public sector entities (except for universities) have been referred to too little. We assume that analysis problems and methods in the public sector require a separate research due to the specific character of their operations. In this regard, universal methods and those which are most applicable to analysis of the public sector entities' operations should be distinguished, as well as the limitations related to applying certain methods developed for the private sector, to the public sector.

\section{Analysis Methods of IP in the Public Sector Used by Foreign and Russian Scientists}

The objectives of our research did not comprise an exhaustive segmentation of the topic in order to select the research topics. However, we distinguished the fields within which the authors define the research problems, which include:

- researchers' human personality and behavioural characteristics, which influence patenting, including the discussion of what is of higher preference and priority for scientists, i.e. patenting, or publishing of scientific findings;

- IP management and strategy development;

- academic and technological cooperation and collaboration between public sector and commercial sector entities;

- intellectual activity regulation and institutional environment.

In the majority of published papers the selected topics overlap and certain issues prevail. Thus, Y.H. Wu, E.W. Welch and W-L. Huang distinguished institutional and personal factors related to human personality characteristics of researchers which influence the prospects of licensing IP items of USA universities [14]. N. Halilem, N. Amara, J. Olmos-Peñuela and M. Mohiuddin studied the influence of three political aspects in the field of IP (attachment of exclusive rights, disclosure duty and profit distribution principles) on the entrepreneurial behaviour of scientists from Canadian universities [15].

S. Öcalan-Özel and J. Pénin defined the advantages and drawbacks of the two key strategies of universities: patenting of research and development results, or their publications paying special attention to the universities' attempts to maximise the social effects of their activity instead of profits [16]. Opposing patenting as a tool used in the "closed partnership" model to publishing of scientific findings which promotes the "open science" model, J. Chataway, S. Parks, and E. Smith note that negative consequences of patenting manifest themselves when it is conducted too early in research stages. Mainly implementing the comparative method, they emphasise that at present there are no researches which use quantitative data and methods to justify the preference for patenting over publishing of research and developments results [17]. The widest range of issues was considered in the research on IP management where the issues of management strategies development were of primary importance. So, J. de Beer, I.P. McCarthy, A. Soliman and E. Treen offered an 
approach which implies choosing one of the four strategies of IP crowdsourcing: passive, possessive, persuasive or prudent, taking into consideration two key factors: intention to gain exclusive rights to IP, and risks related to infringement of third-party rights when using the IP obtained as a result of crowdsourcing deals. A combination of the factors which may manifest themselves at a low or high level in certain situations analysed by the authors determines the choice of a strategy [18]. Those public sector entities which, as a rule, try to appropriate exclusive rights and pay insufficient attention to the verification of infringement of third parties' rights as a result of transactions made by such entities, are characterised more by the possessive strategy. For the purpose of commercialisation, a subsequent transfer of IP to startups is possible. According to N. van Stijn, F.J. van Rijnsoever and M. van Veelen, it is least preferable for the universities engaged mainly in fundamental research, and most preferable for engineering and technical universities [19].

When implementing innovative activity strategies it is important to evaluate the managerial staff's efficiency. S. Veltri and P. Puntillo analysed management practices using the case study and interview methods, and established that effectiveness of human capital management is a more significant parameter of managers' efficiency evaluation in comparison to other components of intellectual capital including IP management [20].

A central issue of several research studies is the cooperation of public sector and commercial sector entities aimed at enhancement of efficiency of scientific research and provision of technology transfer. According to the results of interviewing the managerial staff from 737 Spanish and European innovative companies conducted by M. Fernández-Esquinas, H. Pinto, M.P. Yruela and T.S. Pereira use of IP turned out to be the most rare cooperation mechanism, along with joint-ventures foundations. Staff training is most widely spread and joint research and collaborations for the purpose of use of specially made equipment are a little less widespread [21]. M. Bikard, K. Vakili, F. Teodoridis established (on the basis of the data on the study personnel's published papers and patents) that the team members collaborating with companies publish their papers more actively than academic team members. They outline feedback concerning patenting [22]. Possible reason for that include that companies often take a hard line when it comes to conferring to them exclusive rights to IP items created as a result of joint projects with universities. However, O. Gretsch, F. Tietze and A. Kock found out that the milder the way in which the issues of sharing the rights and coming to an agreement on other contractual terms between the collaboration participants are settled, the more efficient their joint activity is [23].

A number of authors place attention on the issues of intellectual activity regulation on the level of individual economic entities, as well as on the institutional level. In these cases mainly qualitative methods are applied for analysis, including comparative analysis. Thus, D.J. Jefferson, M. Maida, A. Farkas, M. Alandete-Saez and A.B.
Bennett conducted a comparative analysis to define similarities and differences in the programs in the field of IP management, technology transfer and entrepreneurship used by five top American research institutes, paying special attention to disclosure of information on inventions, IP, legal protection and licensing strategies, and the policy of settlement of concerned parties' conflict of interests in the innovation sector which is extensively studied by USA universities - and to a lesser extent, by Latin America universities [24].

\section{Kalantaridis, M. Küttim, M. Govind and C. Sousa} carried out the comparative analysis of institutional conditions which influence spread of knowledge and technology transfer in Great Britain, Portugal, Estonia and India and considered eight cases in four top universities of the above countries. The scientists made an important conclusion that concentration of development results protected as IP and founding of communities for certain knowledge branches on the basis of universities facilitates global commercialisation to a greater extent than the provision of formal (including legislative) conditions and may form an alternative to institutionalisation of the innovative sector [25]. At the same time D.M. Weckowska, J. Molas-Gallart, P. Tang et al. came to the contrary conclusion that national legislation may stimulate development of IP management practices in corresponding countries and regions and this, in turn, has a positive effect on patenting in universities [26].

Over recent years, scientists more often criticise the established statistical approach to assessment of research effectiveness based upon such key measures as the number of published papers, the number of submitted patent applications, and the number of granted patents. Such parameters make it impossible to assess the actual contribution of this activity to the community welfare and also to evaluate the effects for individual economic entities. The paper by T. Mets, A. Kelli, A. Mets and T. Tiimann is dedicated to the development of a new system of qualitative and quantitative strategic indicators which facilitates scientific cooperation and the encouragement of commercialisation of university development results. The indicators system offered by the authors is customised for public, commercial sector entities and the government (region) in general [27].

G. Fernandes, E.B. Pinto, M. Araújo, P. Magalhães and R.J. Machado offered a method of quantitative evaluation of effectiveness of the research conducted by universities and business partners within joint projects or programs and practical recommendations for its use. On the basis of analysis of the project life cycle, the authors developed a system of backward-looking and forward looking, quantitative and qualitative indicators which comprise inter alia patent and publishing performance indicators [28]. I. Stefan and L. Bengtsson also analysed implementation of innovation processes at various stages but did it from the point of view of effects from collaborations with different groups of partners. The authors established that cooperation with universities at early stages allows to increase 
the novelty of developments and this is confirmed by the predominance of research in university-business cooperation [29].

M. Grazzi, C. Piccardo, C. Vergari evaluated the relation between innovation activity indicators (patents and trademarks) and financial operational performance indicators (income and profit) by building algorithmic relations with a probability estimate. The authors made the conclusion that it was a positive relation and studied the effects of patent use in comparison to trademarks. This information may be used to develop strategies [30]. Meanwhile, the method applied by the authors was not new. It was considered for the study of similar relations by T.J. Lybbert and N.J. Zolas [31].

Thus, in the analysis of management practices, institutional conditions of innovative activity and behavioural aspects of invention activities, nonquantitative analysis methods were mainly used. Foreign authors apply quantitative methods in their research studies related to effectiveness assessments of patent and licensing activity, research activity in general or collaborations in the field of research and development (Appendix 1).

When analysing Russian scientists' published papers it should be noted that top priority is given to the development of the most general theoretical and methodological provisions (A.D. Sheremet, M.V. Mel'nik, M.I. Bakanov, R.S. Saifulin, G.V. Savitskaya et al.) [32-34]. On this basis they are followed mainly by economic and financial analysis methods related to evaluation of the structure, dynamics of financial and economic indicators including yield on capital investment, profit and profitability level, intangible assets liquidity etc. and the influence of certain factors on their change (N.V. Zhuravleva, K.I. Kremer, E.M. L'vovich, Yu.V. Prokop'eva, I.P. Mistyukova et al.) [35-41]. The ratio method gained a widespread use. It was used as a tool of innovation, marketing, investment analysis of IP (N.N. Ilysheva, S.I. Krylov, O.V. Mikhailov) [42-44], managerial analysis of intellectual assets (S.A. Kuzubov) [45], and financial analysis of intangible assets utilisation (N.M. Balakireva) [46]. For risk assessment and management of the innovation business the authors offer to apply the options method (R.P. Bulyga) [47], the reflexive analysis method and expert analysis (V.B. Gusev, N.A. Isaeva) [48-50] but in general econometric, mathematical and probability analysis methods are used in the Russian scientists' papers to a substantially smaller degree (Appendix 2). The approach of "translating theory into practice" predominant with Russian scientists differs significantly from the foreign approach where methods are developed and modified on the basis of certain research problems.

In comprehensive interdisciplinary research, economic analysis methods may be efficiently combined with patent analytics methods, which help to study academic and technological development fields on the basis of patent information. M. Holgersson and S. van Santen emphasise that patent analytics as a tool of technological foresight, assessment of technology development level, patent portfolio construction, defining competitors, search for partners in certain fields, and patent infringement risk assessment, has been widely used in academic papers since the early 1990s. The second important category of patent information analysis is patentability assessment, and choice of the types of items' legal protection taking into consideration specifics of the national legislation, industry characteristics and other factors. It is important to note that the authors attributed the researches aimed at strategy development, improvement of mechanisms of IP legal safeguard and protection and other issues to the macro level, while the research studies focused on IP efficiency management were defined at the level of individual economic entities [1]. This approach is in general consistent with the understanding of the Russian scientists (Appendix 3).

The main methods of preparing industry-specific and express patent landscape reports have been developed by the World Intellectual Property Organization. Specialists of the Federal Institute for Industrial Property (FIIP) analysed the methods of patent landscape development applied by WIPO, patent offices of Great Britain, Australia, Switzerland, etc., as well as foreign business companies rendering services of patent landscapes development. They prepared instructional guidelines for patent landscape designing when performing scientific research, titled NIR 9-EP-2014 (НИР 9-ЭП-2014), "Study of Methods for Preparing Patent Landscape Reports as a Tool of Management Decision Making in the Field of Research and Development".

The industry-specific patent landscape is the most complex patent analytical investigation targeted at identifying that technology which is most important for solving the problems of development within an industry. It also seeks to identify the development of patenting strategies and introduction of goods made by the leading industry sector companies in the market, on the basis of an in-depth technical analysis with a multilevel expert interpretation [51]. An express landscape is designed on the basis of an in-depth analysis of the engineering solutions (patterns), most typical of a certain technological development stage, and detection of "anomalies" indicative of a change in the development thrust. This allows one to define the top global development centers, the owners of the most valuable technology, and to forecast the rate of introduction of new technology in the markets. The specific features of express patent landscapes as a type of patent analytical investigation and their difference from industry-specific patent landscapes are described by specialists of the Project Office of FIIP [52]. In that context, A.S. Nikolaev [53]. A. Oplachko determined the key issues of patent landscapes use in companies' management activity. They include a lack of skilled professionals, low integration of patent analytical, management activity, and business processes [54]. A. Abood and D. Feltenberger showed the possibilities of applying the machine learning method for patent landscapes design [55] while J.A. Smith, Z. Arshad, A. Trippe et al. analysed the quality and structure of patent landscape reports in order to elaborate recommendations for their improvement [56]. 
Patentability assessment is one of traditional and most frequent types of research comprising patent and non-patent data published before submitting an application for patenting of the studied engineering solution. The purpose of such study is to define the possibility and degree of legal protection of an engineering solution within the jurisdictions of the countries chosen for patenting. Russian applicants are recommended to use 'GOST R 15.011-96 System of Products Development' and 'Launching into Manufacture. Patent Investigations' in order to verify patentability and patent purity [57]. In other jurisdictions patentability is assessed in accordance with the national legislation.

Examination for patent purity implies defining the product critical components and search for the patents valid in the certain fields which may be potentially infringed. It is of particular importance when a new product is introduced in the market. The general patent purity research methodology is described most consistently in the papers by V.V. Shvedova who also considers specific features of the patent purity investigation at various stages of research and development [58]. E.P. Skornyakov and M.E. Gorbunova also consider the interrelation between the main types of patent researches and product development stages [59].

The patent technology scouting which contemplates an indepth study of the core companies, technology, products and services in the priority technological field may imply a combination of patent analytics with other methods taking into consideration the raised research problems. Thus, F. Pasimeni, A. Fiorini and A. Georgakaki used patent information to analyse innovative activity. Then, on the basis of mathematical analysis methods they defined the relation between patent information and $\mathrm{R} \& \mathrm{D}$ expenses of corresponding companies and determined the leaders in financing of research and development [60]. The possibilities and prospects of determining academic and technological priorities on the basis of patent information (also for Russian scientific and educational organisations) are shown, inter alia, in the papers by O.P. Neretin [61].

At the microlevel, a technology audit is carried out. On the basis of its results organisation's needs and capabilities are defined concerning product positioning and defining target markets, revealing technology fields of special priority, those which require establishing of technology readiness levels, and defining the innovation sources and means of technology transfer for development of partnership relations in the technology field. V.V. Kerimov advocates the innovative audit theory based on 'Due Diligence' technology which implies exerting operational, financial, tax, legal, potential Due Diligence and Due Diligence influence [62]. V.A. Antonets, N.V. Nechaeva, K.A. Khomkin, V.V. Shvedova also developed a proprietary methodology of technology evaluation [63]. M. Grimaldi, L. Cricelli and F. Rogo offered a technology audit methodology applied to the patent portfolio analysis when technology assessment is performed against the background of the general business strategy and when it allows to choose the patents which comply and do not comply with it for more efficient use of the compliant patents and taking decisions as regards further support and use expediency of non-compliant patents [64].

On the basis of patent data and analysis-of-variance method S.Y. Kim and H.J. Lee established that further patent activity increases and the patent quality improves if an economic entity purchases a significant patent in the technology field. They also found out that universities purchase a lot of patents from non-commercial organisations, research institutes, and other patent co-holders which seemingly contradicts the idea of scientific knowledge and technology transfer from universities. In the authors' opinion, the final objectives and consequences of such purchase require a separate study [65].

Apart from that the results of patent analytical investigations may be used to evaluate the significance of technology and finding patents of high commercial value. One of the most widely used approaches to assessment of invention importance which implies use of the coefficient method has been applied in the papers by V.G. Gmoshinskii and G.N. Fliorent since 1966 [66] and later - in the papers by N.V. Bezsonov [67]. However a substantial drawback of this approach was its failure to contemplate use of 'market criteria of importance' appraisal. Instead, it took into account mainly the parameters characterising the technological essence of an invention. E.P. Skornyakov and M.E. Gorbunova modified the coefficient method taking into consideration evaluation of the invention influence on technological sophistication of the products which presumably or actually will be manufactured using the invention as well as the expenses related to manufacture $[59 ; 68]$. Meanwhile, as a rule, in order to assess the patent's importance and value, foreign authors use market indicators, such as offering price and closing price when making transactions on the exchange [69]. Other indicators include future profit [70] and characteristic features of the patents, including forward and/or backward citations, number of quotes in non-patent sources, number of claims, structure of triadic patent families, patenting geography etc. [64; 71;72].

On the basis of a desk study, a questionnaire survey and a discussion with experts, L. Aristodemou, F. Tietze, N. Athanassopoulou and T. Minshall systematised the existing patent analytics methods and designed a roadmap of their development. They identified artificial intelligence, machine learning, neurolinguistic programming, and some other technologies as the key ones to the development of patent analytics. New visualisation techniques, automated translation technology and methods of patent and economic data interrelated analysis are determined as related technology [7].

At the moment, Russian research studies insufficiently exploit the patent analytics opportunities for solving research problems. Now, patent analytics in Russia develop mainly as a part of consulting focused on the applied aspects and opportunities of various professional data search and visualisation systems. However, it seems that academic interest to analysis of patent information in Russia as well as all over the globe will rise in the following years. 


\section{Objectives and Analysis Methods of Transparency of Public Sector Entities}

The term "disclosure" is construed in the researches dedicated to IP in two ways. In the first case disclosure of the invention contents (technical essence) is discussed which may create threats related to the impossibility of items' legal protection in the future and a decrease of their commercial value [73]. However, some scientists are on opposite side of the issue. So, T. Peters, J. Thiel and C.L. Tucci, after analysing cases of various companies, showed that a "strategic disclosure", understood as an intentional disclosure of information on a new engineering solution which impedes patenting of the same solution or the one similar in content by other applicants may create competitive advantages and provide economic benefits [74].

The second side of the research is related to the analysis of disclosure of information not related to the essence of engineering solutions, but used to justify management decisions and develop strategies in the IP field, including indicators of scientific and technological activities, financial-economic and other indicators which characterise innovation processes and their results. Public sector entities submit these indicators in annual reports, separate intellectual capital reports, accounting (financial) reports, scientific reports, sustainable development reports and in other forms. F. Castilla-Polo and C. Ruiz-Rodriguez established that the majority of authors in $77 \%$ of cases use the annual report as the main source of information in the disclosure analysis [9]. However B. Cuozzo, J. Dumay, M. Palmaccio and R. Lombardi offer to differentiate the notion of "disclosure" and "reports" and for research purposes consider "disclosure" in the widest sense, not to be limited to statutory reports or even to voluntary reports including, for example, the integrated reporting concept. Nowadays information is often disclosed digitally and, in the authors' opinion, any "digital source" should be considered as an information base for disclosure analysis [10].

The widest range of disclosure analysis methods was used in the paper by I.M. Welpe, J. Wollersheim, S. Ringelhan and M. Osterloh. Thus, the correlation analysis allowed the authors to define redundant parameters in the Intellectual Capital Report made by universities of Austria which are not informationally useful for concerned parties. These parameters are excluded from further analysis because they may compromise the quality of its results. The factorial analysis is used by the same scientists in order to reveal hidden variable factors responsible for existence of linear statistical correlations between the observed variables. On the basis of the absence of such factors, they made the conclusion that the models obtained as a result of the regression analysis are reliable. The authors also applied the frontier analysis to evaluate performance efficiency of the decision-making units in Austrian universities. As such, the results of this analysis were expressed in percentages, where $100 \%$ meant an entirely effective unit. The authors applied the fuzzy logic methods which are characterised by high flexibility, and enabled them to analyse financial, non-financial, quantitative and qualitative indicators to construct an expert system where the knowledge database contains facts (statistical information in a certain field) and information analysis rules laid down by experts. The model of such an expert system is represented by a decision tree, the branches of which describe parameters of structural, human and relational capital. It allows to assess the most probable changes of each capital type [75].

Content analysis is, perhaps, the most common method of disclosure analysis. It is conducted by various authors on the basis of the search terms system. The number of terms mentioned in the reports is, as a rule, evaluated by a specially designed software. At the same time B. Kamath notes that quantitative (volumetric) parameters of disclosed information make it impossible to characterise unambiguously the disclosure level because it is also necessary to take into account the quality of disclosed information. However, he thinks that it is possible to assume that the amount and quality change simultaneously [76]. A number of authors in order to assess the disclosure level and the disclosed information quality in addition to content analysis offer to apply qualitative methods, including interviews, case studies, and some other methods. Another significant limitation of content analysis use is the current terminological ambiguity related to the meaning and correlation of the notions "intellectual capital", "intellectual property", "intangible assets", "intellectual assets" and other related terms which should be eliminated by theoretical researches. In the practice of content analysis, modification of search queries by adding and excluding various terms causes substantially varying results, thus, decreases the reliability of research and calls into question the key conclusions $[9 ; 10])$.

P. Catalfo and I. Wulf combined content analysis tools with a semantic analysis to study disclosure of IP and intangible assets information in the 'management comments' to the reports prepared in accordance with IFRS and in the evaluation of its sufficiency to satisfy the concerned parties' informational needs [77]. F. Castilla-Polo and C. Ruiz-Rodriguez point out that often content analysis results form the information base for application of statistical methods in assessment of the assets and business value, efficiency and effectiveness analysis etc. [9].

Considering various aspects of disclosure, scientists first analyse the mandatorily disclosed information and indicate that other information is not disclosed due to absence of corresponding requirements or because it is incomplete, incommensurable and, consequently, not suitable for application in all researches. Also the researches which analyse whether the actually disclosed information complies with the requirements established by accounting and reporting standards are widespread [78; 79]. Their authors, in most cases, apply the index method. The model of construction of the disclosure index implies indicating in the numerator the actual volume of the disclosed information measured in points, the number of search terms used in content analysis etc., and in the denominator - the maximum possible volume of information. Besides, the 
authors often use indexes for further regression analysis aimed at revealing the disclosure determinants. Thus, B. Kamath uses the disclosure index as a dependent variable in the multiple regression model [76] while S. Fontana, D. Coluccia and S. Solimene use the value added intellectual coefficient (VAIC) as a factor in the model applied for assessment of the general disclosure level [80].

M. Kachouri and A. Jarboui showed use of the disclosure index in establishing the relation between corporate reporting and corporate management efficiency [81]. At the same time A. Maaloul, W. Ben Amar and D. Zeghal applied the correlation-regression analysis and established that the intangible assets disclosure level has a positive effect on forecasting profitability evaluations created by experts [82].

However the disclosure index may be applied to analyse public sector entities' transparency, not just using the information subject to mandatory disclosure, but also the voluntarily disclosed information. In this regard, the three-level model of IP and patent strategy disclosure is of great importance. It contemplates selection of the information to the extent which is minimally required, and mandatory for disclosure by all economic entities (the first level), recommended information disclosed taking into consideration the correlation of expenses and results related to its preparation (the second level) and additional information (the third level), which may be disclosed or not disclosed in the corporate reporting on a variable basis [83]. Here, the author relies upon the true and fair disclosure concept and the materiality concept, and four effective communication principles in corporate reporting stated in the report of the Financial Reporting Council of Great Britain (named "Louder than Words") [84]:

- focus on the information which is of the most interest for users;

- transparency and honesty;

- clearness and comprehensibility;

- interestingness and attractiveness of information for users.

Among the indicators offered by the author, he describes an expanded amount of information on the corporate patent portfolio and characteristic features of some patents, license agreements, uncertainty risks related to patenting and IP management (which exercise a significant influence on assessment of the item's fair value where it was noticed that many companies may overestimate or underestimate it). The author also emphasises that voluntary disclosure of additional information characterises dynamics of corporate strategic development. Along with this, on the basis of the regression analysis F. Schiemann, K. Richter, T. Günther established the presence of negative relations between the intangible assets information disclosed in accounting (financial) reports and the knowledge capital data disclosed voluntarily. This attests to the fact that such information may be redundant for the concerned parties' decision making [85].

Thus, use of various methods in the disclosure analysis is intended to improve the information quality and select relevant data for further analysis conducted for management purposes as well as to estimate the general level of transparency of public sector entities (Appendix 4).

F. Castilla-Polo and D. Gallardo-Vázquez combined the key goals of disclosure into two groups [8]:

- goals related to accounting (a substantial influence of intangible assets on estimation of the company value, their importance for taking management decisions in the financial field, including the ones related to resource distribution); we would like to add statutory requirements to them;

- goals not related to accounting (anticipated rise in incomes, business value, strengthening of reputation and willingness to satisfy the concerned parties' informational needs on the basis of voluntarily assumed obligations of disclosure).

The authors consider that the factors impeding disclosure are the risk of possible competitiveness loss, lack of necessary expertise, and conservatism. However they think that these are indirect influence factors. Therewith, the direct and most significant influence is exerted by the factors related to the problems of identification, measurement and assessment of IP and intangible assets as well as absence of sufficient theoretical and methodological grounds for disclosure. This is the most serious lacuna in modern researches. Along with that, the authors assume that it is impossible to develop such grounds inductively, on the basis of existing practices. A more profound theoretical research is necessary.

When there are no basic grounds for making decisions on disclosure, virtually the only criterion is the balance between benefit and cost. However, such an approach brings us back to the discussion of effectiveness measurement. Another consequence is the fact that even in the case of taking a decision on disclosure development of the further "disclosure strategy" which defines the content, amount of disclosed data, form of disclosure and other aspects becomes very difficult.

Apart from that, consistency of methodology of disclosure and IP management is of crucial significance. It will allow to improve the information usefulness for taking management decisions. Differentiation and defining these aspects in detail for various economic entities' groups including small business entities, business leaders, non-commercial organisations and public sector entities, are also a necessary precondition for improvement of the information quality and usefulness for various users' groups. The majority of authors define them as a promising vector of research development in the field of disclosure analysis. We presume that only after these important theoretical and methodological objectives are achieved will a justified comparative assessment of the extent of public sector entities' transparency be possible. 
Table 1. Analysis fields and methods recommended for use at various stages of the reciprocal model

\begin{tabular}{|c|c|c|}
\hline $\begin{array}{l}\text { Stages of the recip- } \\
\text { rocal model }\end{array}$ & Analysis field & Recommended analysis methods \\
\hline Stage 3 & $\begin{array}{l}\text { Analysis of the amount, dynamics, state, } \\
\text { structure and utilisation efficiency of } \\
\text { intangible assets }\end{array}$ & $\begin{array}{l}\text { Horizontal analysis, vertical analysis, ratio analy- } \\
\text { sis, factorial analysis, balance method, compari- } \\
\text { son method etc. }\end{array}$ \\
\hline Stage 4 & $\begin{array}{l}\text { Choice of fields and risk evaluation of the } \\
\text { innovation activity, choice of commer- } \\
\text { cialisation ways of IP }\end{array}$ & $\begin{array}{l}\text { Options method, discounting, correlation-re- } \\
\text { gression analysis, simulation modeling, patent } \\
\text { analytics tools etc. }\end{array}$ \\
\hline Stage 6 & $\begin{array}{l}\text { Assessment of IP utilisation efficien- } \\
\text { cy against the background of strategic } \\
\text { tasks and defining further development } \\
\text { pathways }\end{array}$ & $\begin{array}{l}\text { Economic-and-mathematical and econometric } \\
\text { methods, stochastic analysis methods, prob- } \\
\text { abilistic method, reflexive analysis, nonlinear } \\
\text { dynamics methods etc. }\end{array}$ \\
\hline
\end{tabular}

\section{Results Discussion}

We tried to solve the above theoretical and methodological problems, and in doing so set forth the principles, conceptual foundations of accounting and analytical support of IP management and develop a reciprocal model of accounting and analysis of IP in the public sector comprising identification and commercialisation of items [11; 12].

The offered model consists of three stages where analytical tools are used:

- $\quad$ stage 3 , the final stage of identification;

- $\quad$ stage 4 and 6 , respectively, the first and final stage of commercialisation.

So, while performing identification (stage 3) the amount, dynamics, state, structure and use of items is analysed as components of the corporate asset complex identified as a part of intangible assets. At the same time, for performing commercialisation, analysis methods are applied first in order to choose the innovative activity fields and ways of IP commercialisation (stage 4) and, second, in order to assess efficiency of IP utilisation against the background of fulfillment of the strategic tasks of the public sector entities (stage 6).

In this case, the analytical methods considered within our survey research may be systematised in accordance with the stages of the offered reciprocal model of IP accounting and analysis in the public sector (Table 1).

The majority of the methods applicable at the stage 3 to analyse the structure, dynamics, state, flow of intangible assets as well as the extent and efficiency of their use, which are measured on the basis of indicators of turnaround, return and cost-effectiveness of intangible assets as a part of the corporate asset complex was considered primarily by Russian scientists. Analysis methods and tools used at the stage 4 to choose the most promising fields of research and development, innovative activity, and ways of its results' commercialisation, as well as the methods applied at the sixth stage in order to evaluate efficiency of IP utilisation against the background of fulfillment of strategic tasks (and defining further development pathways of a public sector entity) are used mainly in the published papers of foreign scientists and some papers by Russian scientists. In general they require further development. Patent analytics tools have a high potential for solving the tasks at the stage 4 .

At the stage 6 one chooses further development pathways in innovations and forecasts a public sector entity's operations under risk and uncertainty. In our opinion, economic-and-mathematical and probabilistic methods may be used to solve these problems. We also offer to expand these methods by applying nonlinear dynamics methods, in particular, the channels and jokers method described by G.G. Malinetskii and A.B. Potapov in the analysis of public sector entities transparency [86]. Prerequisites of this method application consist in the fact that it has proved its efficiency in economic research, in particular, in risk assessment and management [87], macroeconomic processes modeling [88] and modeling of insurance companies' operations [89]. However special attention should be paid to the papers by A.A. Minaev and G.A. Minaev, the founders of the dynamic theory of innovation, who showed the potential of nonlinear dynamics methods in a study of dynamic patent systems [90; 91].

Alongside that, there has been no research dedicated to application of nonlinear dynamics methods in order to determine the development pathways of public sector entities conducted on the basis of analysis of information capacity and information quality established in accounting and disclosed in the reports. This defines the novelty and originality of the offered approach.

The research hypothesis generated from the perspective of the application of nonlinear dynamics methods states that public sector entities' transparency level, and the characteristic features of disclosed information may be used to identify the state of entities as dynamic systems and to define the pathways of their further development. For a theoretical demonstration of the hypothesis, we use the space-time coordinate system (Figure 1) which represents projections of the dynamic economic system (channels G1-G3) and its movements caused by probability laws (jokers J1-J3). 
Figure 1. Behaviour of the dynamic economic system in the space-time coordinate system

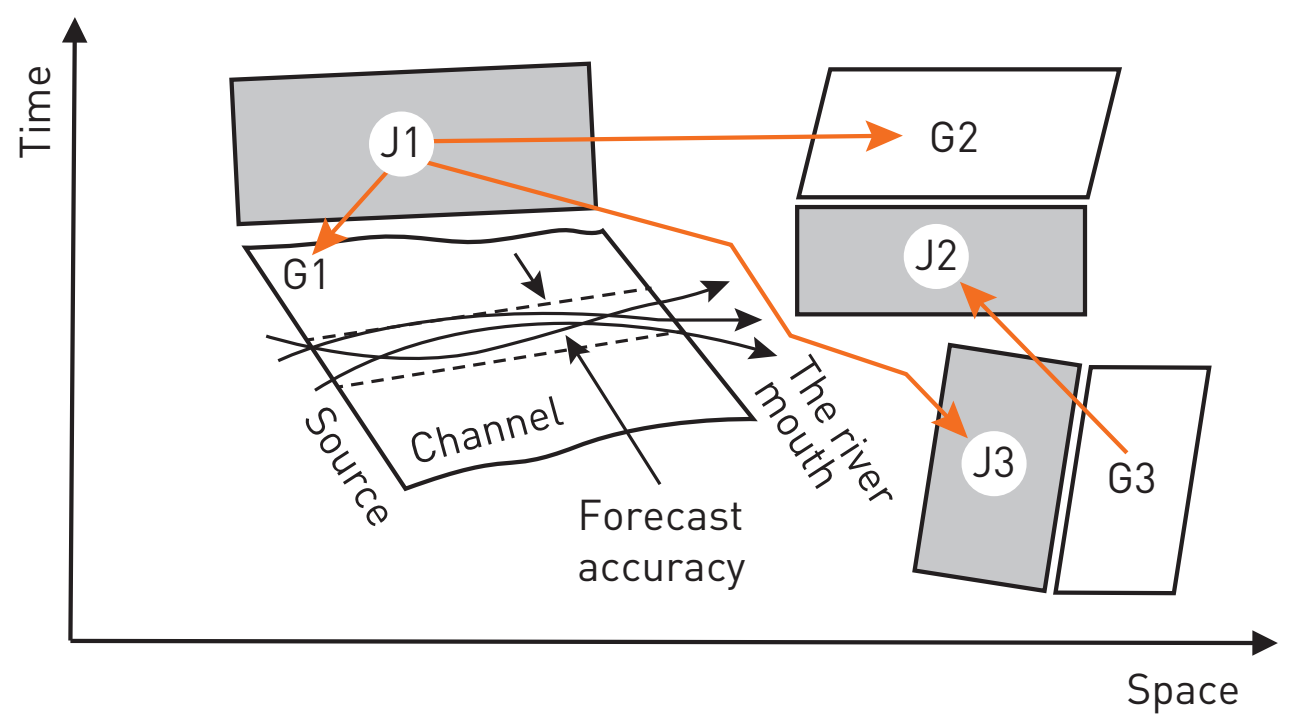

Figure 1 shows that at any given time, a public sector entity, as a dynamic economic system, is at some point of the space-time continuum lying within a certain channel. Therewith the following consistent patterns are observed. When an entity is at the channel source its behaviour and development forecasts are to a great extent determined by statistical laws, and functional dependencies between the activity indicators, mainly financial ones. Under such circumstances the activity may be forecasted on the basis of financial analysis and planning methods, while the level and characteristic features of disclosed information are the minimum required for applying such methods, mainly limited to accounting (financial) reports which comply with legislative requirements to its preparing and submitting.

The entities which disclose a wider range of indicators are searching for the trajectory which ensures sustainable development between the channel source and mouth. Analysis of such indicators (financial and non-financial ones which are disclosed in various forms of accounting and other reports) is conducted using a wide range of methods of factorial analysis, correlation-regression analysis, simulation modeling etc., and allows the concerned parties to take decisions which adjust the entities' movements between various trajectories within a channel. In this case, the level and characteristic features of disclosed information comply not just with the legislation but also with the informational needs of concerned parties.

Finally, the entities which disclose the largest amount of information approach the channel mouth. It is confirmed by an increase in the amount of disclosed "information noise", i.e. the information which is redundant for the justification of decisions by the concerned parties and for forecasting of sustainable development within the channel. Analysis of such redundant information shows contradictory results which just partially meet the criteria specified within the channel. In our opinion, this redundancy occurs where the manifestation of "bifurcation" may be found. It is indicative of the transfer of quantita- tive changes into qualitative ones as the dynamic system develops.

Thus, measuring of the level and characteristic features of disclosed information allows to identify the approach of the system initially functioning in channel G1 projection to the joker area (J1), where such laws are in effect which may possibly transfer the system to another channel area (for example, G2 or bring it back to channel G1 as illustrated in Figure 1) as well as another joker area (J3). In this case, the stochastic motion will continue till the moment when the system approaches the source of a new channel.

It should also be noted that the application of the channels and jokers method in the IP analysis offers opportunities to establish interrelations between microeconomic factors and macroeconomic conditions of conducting innovative activity. It is of special importance for ensuring sustainable development of public sector entities and achievement of public management objectives in science and innovations.

\section{Summary and Conclusions}

In this paper we conducted a survey research comprising 10 previously-published survey papers, 42 special issue materials by foreign authors, and 39 Russian sources dedicated to various management issues as well as accounting issues and IP and intangible assets disclosure issues in order to generalise and systematise the methods applied by the authors. It was established that in the management practices analysis as well as analysis of organisational, behavioural and institutional aspects of intellectual activity, qualitative methods were mainly applied. Interview, questionnaire survey, and case study methods are the most widely used ones. Foreign authors use quantitative methods (mainly regression and correlation analysis) in their research studies, which implies evaluation of innovation activity efficiency and its influence on financial and economic indicators of the public sector entities' operations. 
Russian scientists tend to mainly consider economic and financial analysis methods related to assessment of the structure and dynamics of various financial and economic indicators. Factorial and ratio analysis methods were widely used. Some authors offer to apply the options method, reflexive analysis method and expert analysis but in general econometric, mathematical and probability analysis methods are applied substantially less often in Russian scientists' papers. At the same time the Russian scientists' deductive approach contemplating, first of all, development of the most general theoretical and methodological provisions differs significantly from the approach of foreign authors, where methods are developed or modified on the basis of certain research problems. This is the most substantial difference between the Russian and foreign analytical approaches. This crucial difference manifests itself not just in the research logic and results but also in the way they are represented. In the international practice, the most typical way of presenting the results is a scientific paper, while Russian scientists publish the most important research results, including the contents of the developed methods in research monographs and educational editions.

In recent years, increasingly greater attention is paid to the tools of modern patent analytics which have a high potential for solving the problems of defining the key partners and competitors, priority research topics and markets. The corresponding tools are well-developed, and are used by foreign authors. However, broad perspectives are related to the use of the patent analytic tools in combination with economic analysis methods for solving the problems of monetary estimates of IP items, efficiency evaluation of the public sector entities' innovative activity, and other management problems which need an interrelated analysis of patent and economic data. The key technologies which predetermine development of patent analytics were also defined. They comprise artificial intelligence, machine learning, neurolinguistic programming and some related technologies including new visualisation techniques and automated translation technology. Up-to-date Russian research mainly reveals the results of statistical analysis of the patent and license activity while patent analytics in Russia just starts evolving mainly as a part of consulting.

Improvement of the tools of IP analysis in the public sector is closely connected with the opportunities to expand the analysis information base. In this regard generalisation of the disclosure analysis methods was a separate research issue. It was established that content analysis of reports submitted in various formats (statutory financial accounts, voluntary reports on intellectual capital, sustainable development etc.) was most widely used. Also the authors extensively use disclosure indexes, often constructed on the basis of content analysis results. Meanwhile insufficient development of theoretical and methodological grounds for disclosure substantially restricts application of this method, as well as development and use of new tools. First of all it manifests itself as termino- logical ambiguity of the notions "intellectual property", "intellectual capital", "intangible assets" and some others.

At present the choice of a term often depends on the author's preferences and has no necessary justification. On the one hand, it occludes comprehension of the logic of existing research papers where the same term is used in different senses. On the other hand, within thematic studies and application of the content analysis method this presents problems with choice of key words. We have not used the term "intellectual capital" in this paper as a search query for bibliographic databases because it was established that it has a very wide context of use which comprises, in particular, a wide range of human resource management and reputation management issues which are beyond the topic of our research. The scope of this research was limited to analysis of intellectual activity results protected as IP, and recognised in intangible assets of public sector entities.

It was also established that an increase in the amount and quality of disclosed information is hindered by absence of sufficient theoretical and methodological grounds for disclosure which define the contents, amount of disclosed information, disclosure form and a series of other aspects. This requires further research in this field. Apart from that, consistency of methodology of disclosure and IP management is of crucial significance. It will allow to improve the information usefulness, and benefit those taking management decisions.

We developed and presented a new theoretical and methodological approach to fill in the identified lacunas. The approach comprises the reciprocal model of IP accounting and analysis in the public sector. It systematises the considered analytical methods in accordance with the stages of the offered model. It is also shown that at the final stage, in order to determine the further development pathways of public sector entities, the model provides an opportunity to use nonlinear dynamics and the dynamic theory of innovation methods (patent information).

Finally, further research into various categories of economic entities (in particular public sector entities) are of crucial significance. The majority of authors write about the dearth of such researches. In our review we pay the main attention to universities because in existing research universities are often independent subjects of research. At the same time, the authors of published papers paid substantially less attention to the activities of scientific institutions, state-owned enterprises and corporations, as well as other public sector entities. The absence of a sufficient number of researches focusing on the public sector prevented us from solving to the fullest extent the research problem related to assessment of applicability in the public sector of various analytical methods widely used in the commercial sector. This means that it is necessary to continue to promote further research in this area. 


\section{References}

1. Holgersson M., van Santen S. The business of intellectual property: A literature review of IP management research. Stockholm Intellectual Property Law Review. 2018;1(1):44-63.

2. Holgersson M., Aaboen L. A literature review of intellectual property management in technology transfer offices: From appropriation to utilization. Technology in Society. 2019;59:101132. DOI: 10.1016/j.techsoc.2019.04.008

3. Mascarenhas C., Ferreira J.J., Marques C. Universityindustry cooperation: A systematic literature review and research agenda. Science and Public Policy. 2018;45(5):708-718. DOI: $10.1093 /$ scipol/scy003

4. Yaghoubi M., Teymourzadeh E., Bahadori M., Ghardashi F. Conceptual model of innovation capability in industrial and academic research centers: A systematic review. Iranian Journal of Management Studies. 2017;10(3):609-640. DOI: 10.22059/IJMS.2017.238379.672756

5. Maresova P., Štemberková R., Fadeyi O. Models, processes, and roles of universities in technology transfer management: A systematic review. Administrative Sciences. 2019;9(3):67. DOI: 10.3390/ admsci9030067

6. Aristodemou L., Tietze F. The state-of-the-art on intellectual property analytics (IPA): A literature review on artificial intelligence, machine learning and deep learning methods for analyzing intellectual property (IP) data. World Patent Information. 2018;55:37-51. DOI: 10.1016/j.wpi.2018.07.002

7. Aristodemou L., Tietze F., Athanassopoulou N., Minshall T. Exploring the future of patent analytics: A technology roadmapping approach. Centre for Technology Management Working Paper Series, 2017;(5). URL: https://www.repository.cam.ac.uk/ bitstream/handle/1810/269032/17_05_Aristodemou_ et_al.pdf? sequence $=1$ \&isAllowed $=\mathrm{y}$

8. Castilla-Polo F., Gallardo-Vázquez D. The main topics of research on disclosures of intangible assets: A critical review. Accounting Auditing \& Accountability Journal. 2016;29(2):323-356. DOI: 10.1108/AAAJ-112014-1864

9. Castilla-Polo F., Ruiz-Rodriguez C. Content analysis within intangible assets disclosure: A structured literature review. Journal of Intellectual Capital. 2017;18(3):506-543. DOI: 10.1108/JIC-11-2016-0123

10. Cuozzo B., Dumay J., Palmaccio M., Lombardi R. Intellectual capital disclosure: A structured literature review. Journal of Intellectual Capital. 2017;18(1):928. DOI: 10.1108/JIC-10-2016-0104

11. Khomenko E. Modeling of accounting and analytical processes in the educational and scientific organizations for effective commercialization of intellectual property. Audit i Finansovyj Analiz= Audit and Financial Analysis. 2018;(5):197-202. (In Russ.).

12. Khomenko E. Reverse methodological approach in accounting and analysis of intellectual property of public sector entities. Audit = The Audit Magazine. 2020;(3):15-20. (In Russ.).

13. Buonomo I., Benevene P., Barbieri B., Cortini M. Intangible assets and performance in nonprofit organizations: A systematic literature review. Frontiers in Psychology. 2020;11:729. DOI: 10.3389/ fpsyg.2020.00729

14. Wu Y.H., Welch E.W., Huang W.-L. Commercialization of university inventions: Individual and institutional factors affecting licensing of university patents. Technovation. 2015;36-37:12-25. DOI: $10.1016 /$ j.technovation.2014.09.004

15. Halilem N., Amara N., Olmos-Peñuela J., Mohiuddin M. “To own, or not to own?” A multilevel analysis of intellectual property right policies' on academic entrepreneurship. Research Policy. 2017;46(8):14791489. DOI: 10.1016/j.respol.2017.07.002

16. Öcalan-Özel S., Pénin J. Exclusive or open? An economic analysis of university intellectual property patenting and licensing strategies. Journal of Innovation Economics. 2016;3(21):133-153. DOI: 10.3917/jie.021.0133

17. Chataway J., Parks S., Smith E. How will open science impact on university-industry collaboration? Foresight and STI Governance. 2017;11(2):44-53. DOI: 10.17323/2500-2597.2017.2.27.42

18. de Beer J., McCarthy I.P., Soliman A., Treen E. Click here to agree: Managing intellectual property when crowdsourcing solutions. Business Horizons. 2017;60(2):207-217. DOI: 10.1016/j. bushor.2016.11.002

19. van Stijn N., van Rijnsoever F.J., van Veelen M. Exploring the motives and practices of university start-up interaction: Evidence from Route 128. The Journal of Technology Transfer. 2018;43(3):674-713. DOI: $10.1007 / \mathrm{s} 10961-017-9625-5$

20. Veltri S., Puntillo P. On intellectual capital management as an evaluation criterion for university managers: A case study. Journal of Management \& Governance. 2020;24(1):135-167. DOI: 10.1007/ s10997-019-09461-5

21. Fernández-Esquinas M., Pinto H., Yruela M.P., Pereira T.S. Tracing the flows of knowledge transfer: Latent dimensions and determinants of universityindustry interactions in peripheral innovation systems. Technological Forecasting and Social Change. 2016;113(Pt. B):266-279. DOI: 10.1016/j. techfore.2015.07.013 
22. Bikard M., Vakili K., Teodoridis F. When collaboration bridges institutions: The impact of university-industry collaboration on academic productivity. Organization Science. 2019;30(2):426445. DOI: $10.1287 /$ orsc.2018.1235

23. Gretsch O., Tietze F., Kock A. Firms' intellectual property ownership aggressiveness in universityindustry collaboration projects: Choosing the right governance mode. Creativity and Innovation Management. 2020;29(2):359-370. DOI: 10.1111/ caim. 12354

24. Jefferson D.J., Maida M., Farkas A., Alandete-Saez M., Bennett A.B. Technology transfer in the Americas: Common and divergent practices among major research universities and public sector institutions. The Journal of Technology Transfer. 2017;42(6):13071333. DOI: $10.1007 / \mathrm{s} 10961-016-9516-1$

25. Kalantaridis C., Küttim M., Govind M., Sousa C. How to commercialize university-generated knowledge internationally? A comparative analysis of contingent institutional conditions. Technological Forecasting and Social Change. 2017;123:35-44. DOI: 10.1016/j.techfore.2017.06.013

26. Weckowska D.M., Molas-Gallart J., Tang P., Twigg D., Castro-Martinez E., Kijeńska-Dabrowska I. et al. University patenting and technology commercialization - legal frameworks and the importance of local practice. $R$ \& $D$ Management. 2018;48(1):88-108. DOI: 10.1111/radm.12123

27. Mets T., Kelli A., Mets A., Tiimann T. From patent counting towards the system of IP strategic indicators. Inzinerine Ekonomika-Engineering Economics. 2016;27(3):316-24. DOI: 10.5755/j01. ee.27.3.13799

28. Fernandes G., Pinto E.B., Araújo M., Magalhães P., Machado R.J. A method for measuring the success of collaborative university industry R\&D funded contracts. Procedia Computer Science. 2017;121:451460. DOI: $10.1016 /$ j.procs.2017.11.061

29. Stefan I., Bengtsson L. Unravelling appropriability mechanisms and openness depth effects on firm performance across stages in the innovation process. Technological Forecasting and Social Change. 2017;120:252-260. DOI: 10.1016/j. techfore.2017.03.014

30. Grazzi M., Piccardo C., Vergari C. Concordance and complementarity in IP instruments. Industry and Innovation. 2020;27(7):756-788. DOI: $10.1080 / 13662716.2020 .1726728$

31. Lybbert T.J., Zolas N.J. Getting patents and economic data to speak to each other: An "algorithmic links with probabilities" approach for joint analyses of patenting and economic activity. Research Policy. 2014;43(3):530-542. DOI: 10.1016/j. respol.2013.09.001

32. Bakanov M.I., Mel'nik M.V., Sheremet A.D. Economic analysis theory. Moscow: Finansy i statistika; 2004. 534 p. (In Russ.).

33. Savitskaya G.V. Analysis of the economic activity of the enterprise. Moscow: Infra-M; 2016. 378 p. (In Russ.).

34. Saifulin R. Analysis of the efficiency of using intangible assets. Ekonomika i zhizn'. 1995;(27):19. (In Russ.).

35. Zhuravleva N.V., Kremer K.I., L'vovich E.M. Theoretical and methodological foundations of intellectual property accounting and analysis. Voronezh: Nauchnaya kniga; 2007. 140 p. (In Russ.).

36. Prokop'eva Yu.V. Management and analysis of the use of objects of intellectual property of enterprises. Upravlenie $v$ sovremennykh sistemakh $=$ Management in Modern Systems. 2018;(1):3-12. (In Russ.).

37. Prokop'va Yu.V. Comprehensive analysis of the efficiency of using intangible assets. Mezhdunarodnyi bukhgalterskii uchet = International Accounting. 2013;(39):27-40. (In Russ.).

38. Mistyukova I.P., Ryabchenko T.N., Furmanova N.V. Actual problems of accounting, analysis and audit of intangible assets. Nevinnomyssk: Nevinnomyssk Institute of Economics, Management and Law; 2014. 167 p. (In Russ.).

39. Endovitskii D.A., Isaenko A.N., Lubkov V.A., Zhuravleva N.V., Korobeinikova L.S. et al. Economic analysis of organization assets. Moscow: Eksmo; 2009. 608 p. (In Russ.).

40. Krivitskaya K.V. Methodology for the analysis of operations to provide intangible assets of industrial property for use. Ekonomicheskii analiz: teoriya $i$ praktika = Economic Analysis: Theory and Practice. 2012;(39):52-57. (In Russ.).

41. Plaskova N.S., Polyanskaya T.A., Prodanova N.A. Methodology of accounting and analytical support of the innovation management system. Moscow: Infra-M; 2020. 179 p. (In Russ.).

42. Ilysheva N.N., Krylov S.I. Accounting, analysis and strategic management of innovative activities. Moscow: Finansy i statistika; 2014. 216 p. (In Russ.).

43. Ilysheva N.N., Mikhailov O.V. Accounting, assessment and management of intangible assets. Ekaterinburg: Ural State Technical University; 2004. 314 p. (In Russ.).

44. Mikhailov O.V. Improvement of theoretical and methodological aspects of accounting and analysis of intangible assets in commercial organizations. Cand. econ. sci. diss. Synopsis. Ekaterinburg: Ural State Technical University; 2005. 22 p. (In Russ.). 
45. Kuzubov S.A. Intellectual assets: Accounting, analysis and audit. Moscow: Finansy i statistika; 2009. 184 p. (In Russ.).

46. Balakireva N.M. Intangible assets. Accounting, audit, analysis. Moscow: Eksmo; 2005. 414 p. (In Russ.).

47. Bulyga R.P. Methodological problems of accounting, analysis and audit of intellectual capital. Moscow: Financial Academy under the RF Government; 2005. 400 p. (In Russ.).

48. Gusev V.B., Isaeva N.A. Analysis of the impact of intangible assets on the synergistic effect of enterprises' activities. In: Management of large-scale systems development MLSD’2017. Proc. Int. conf. (Moscow, 2-4 Oct., 2017). Vol. 1. Moscow: V.A. Trapeznikov Institute of Control Sciences of RAS; 2017:147-152. (In Russ.).

49. Gusev V.B., Isaeva N.A. Expert analysis of the intangible assets management system considering risk assessments. Problemy upravleniya $=$ Control Sciences. 2017;(1):40-46. (In Russ.).

50. Gusev V.B., Isaeva N.A. Reflexive risk analysis in the management of intangible assets. In: Management of large-scale systems development MLSD'2016. Proc. $9^{\text {th }}$ Int. conf. (Moscow, 3-5 Oct., 2016). Vol. 1. Moscow: V.A. Trapeznikov Institute of Control Sciences of RAS; 2016:226-232. (In Russ.).

51. Trippe A. Guidelines for preparing patent landscape reports. Geneva: World Intellectual Property Organization; 2015. 131 p. URL: https://www.wipo. int/edocs/pubdocs/en/wipo_pub_946.pdf

52. Ena O., Popov N. Methodology for developing patent landscapes of the FIPS project office. Stankoinstrument. 2019;(1):28-35. (In Russ.). DOI: 10 $.22184 / 24999407.2019 .14 .01 .28 .35$

53. Nikolaev A.S. Management of enterprise innovation activity using methods of patent analytics and patent landscapes. Ekonomika. Pravo. Innovatsii. 2019;(2):49-55. (In Russ.).

54. Oplachko A. Implementation of patent landscapes in business processes of holding companies with state participation. Intellektual'naya sobstvennost'. Promyshlennaya sobstvennost' = Intellectual Property. Industrial Property. 2018;(2):23-34. (In Russ.).

55. Abood A., Feltenberger D. Automated patent landscaping. Artificial Intelligence and Law. 2018;26(2):103-125. DOI: 10.1007/s10506-018-92224

56. Smith J.A., Arshad Z., Trippe A., Collins G.S., Brindley D.A., Carr A.J. The reporting items for patent landscapes statement. Nature Biotechnology. 2018;36(11):1043-1047. DOI: 10.1038/nbt.4291

57. GOST R 15.011-96. System of products development and launching into manufacture. Patent investigations. Procedure and scope. URL: http:// docs.cntd.ru/document/5200264 (In Russ.).

58. Shvedova V.V. Study of the patent purity of the object. Moscow: Information and Publishing Center "Patent”; 2015. 214 p. (In Russ.).

59. Skornyakov E.P., Gorbunova M.E. Patent research. Moscow: Information and Publishing Center "Patent”; 2011. 183 p. (In Russ.).

60. Pasimeni F, Fiorini A, Georgakaki A. Assessing private R\&D spending in Europe for climate change mitigation technologies via patent data. World Patent Information. 2019;59:101927. DOI: 10.1016/j. wpi.2019.101927

61. Neretin O.P. Tools for Russian scientific and educational organizations to determine scientific and technological priorities based on patent data. In: World-class scientific publication - 2017: Best practices in preparation and promotion of publications. Proc. $6^{\text {th }}$ Int. sci.-pract. conf. (Moscow, 18-21 Apr., 2017). Ekaterinburg: Ural University Publ.; 2017;90-94. (In Russ.).

62. Kerimov V.V. Theory, methodology and methods of intellectual property audit based on "Due Diligence". Moscow: Dashkov \& Co.; 2014. 102 p. (In Russ.).

63. Antonets V.A., Nechaeva N.V., Khomkin K.A., Shvedova V.V. Innovative business: Formation of models for the commercialization of advanced developments. Moscow: Delo; 2009. 320 p. (In Russ.).

64. Grimaldi M., Cricelli L., Rogo F. Auditing patent portfolio for strategic exploitation: A decision support framework for intellectual property managers. Journal of Intellectual Capital. 2018;19(2):272-293. DOI: 10.1108/JIC-01-2017-0019

65. Kim S.Y., Lee H.J. The effect of patent acquisition on subsequent patenting activity. World Patent Information. 2019;59:101933. DOI: 10.1016/j. wpi.2019.101933

66. Gmoshinskii V.G., Fliorent G.N. Theoretical foundations of engineering forecasting. Moscow: Nauka; 1973. 303 p. (In Russ.).

67. Bezsonov N.V. Methodological guide for calculating the economic effect from the use of inventions and innovation proposals. Moscow: All-Union Scientific Research Institute of Patent Information; 1985. 104 p. (In Russ.).

68. Skornyakov E.P., Tsekhmistrenko N.M., Gorbunova M.E. Patent research in the valuation of industrial property value. Moscow: Patent; 2008. 78 p. (In Russ.).

69. Odasso C., Scellato G., Ughetto E. Selling patents at auction: An empirical analysis of patent value. Industrial and Corporate Change. 2015;24(2):417-438. DOI: $10.1093 / \mathrm{icc} / \mathrm{dtu} 015$ 
70. Jutimongkonkul K., Pentrakoon D., Wonglimpiyarat J. Patent valuation techniques: Practical uses in Thailand. International Journal of Technoentrepreneurship. 2020;4(1):58-75. DOI: 10.1504/IJTE.2020.108097

71. Chang S.-H., Fan C.-Y. A new model for measuring the impact of patent value growth trajectory. International Journal of Technology, Policy and Management. 2017;17(1):40-57. DOI: 10.1504/ IJTPM.2017.083742

72. Tahmooresnejad L., Beaudry C. Capturing the economic value of triadic patents. Scientometrics. 2019;118(1):127-157. DOI: 10.1007/s11192-0182959-4

73. Gans J.S., Murray F.E., Stern S. Contracting over the disclosure of scientific knowledge: Intellectual property and academic publication. Research Policy. 2017;46(4):820-835. DOI: 10.1016/j. respol.2017.02.005

74. Peters T., Thiel J., Tucci C.L. Protecting growth options in dynamic markets: The role of strategic disclosure in integrated intellectual property strategies. California Management Review. 2013;55(4):121-42. DOI: 10.1525/cmr.2013.55.4.121

75. Welpe I.M., Wollersheim J., Ringelhan S., Osterloh M., eds. Incentives and performance: Governance of research organizations. Cham: Springer International Publishing; 2015. 488 p.

76. Kamath B. Determinants of intellectual capital disclosure: Evidence from India. Journal of Financial Reporting and Accounting. 2017;15(3):367-391. DOI: 10.1108/JFRA-01-2016-0003

77. Catalfo P., Wulf I. Intangibles disclosure in Management Commentary regulation in Germany and Italy: A semantic approach. Journal of Intellectual Capital. 2016;17(1):103-119. DOI: 10.1108/JIC-092015-0083

78. Devalle A., Rizzato F., Busso D. Disclosure indexes and compliance with mandatory disclosure - The case of intangible assets in the Italian market. Advances in Accounting. 2016;35:8-25. DOI: 10.1016/j.adiac.2016.04.003

79. André P., Dionysiou D., Tsalavoutas I. Mandated disclosures under IAS 36 Impairment of Assets and IAS 38 Intangible Assets: Value relevance and impact on analysts' forecasts, Applied Economics. 2018;50(7):707-725. DOI: $10.1080 / 00036846.2017 .1340570$

80. Fontana S, Coluccia D, Solimene S. VAIC as a tool for measuring intangibles value in voluntary multistakeholder disclosure. Journal of the Knowledge Economy. 2019;10(4):1679-1699. DOI: 10.1007/ s13132-018-0526-0
81. Kachouri M., Jarboui A. Exploring the relation between corporate reporting and corporate governance effectiveness. Journal of Financial Reporting and Accounting. 2017;15(3):347-366. DOI: 10.1108/JFRA-06-2016-0053

82. Maaloul A., Ben Amar W., Zeghal D. Voluntary disclosure of intangibles and analysts' earnings forecasts and recommendations. Journal of Applied Accounting Research. 2016;17(4):421-439. DOI: 10.1108/JAAR-10-2014-0105

83. Denoncourt J. Intellectual property, finance and corporate governance. Abingdon: Routledge; 2018. $288 \mathrm{p}$.

84. Louder than words: Principles and actions for making corporate reports less complex and more relevant. London: Financial Reporting Council; 2009. 64 p. URL: https://qtxasset.com/cfoinnovation/ field/field_p_files/white_paper/FRC $\% 20$ DiscussionPaper\%20Louder\%20than\%20words.pdf

85. Schiemann F., Richter K., Günther T. The relationship between recognised intangible assets and voluntary intellectual capital disclosure. Journal of Applied Accounting Research. 2015;16(2):240-264. DOI: 10.1108/JAAR-11-2012-0076

86. Malinetskii G.G., Potapov A.B. Modern problems of nonlinear dynamics. Moscow: Editorial URSS; 2000. 336 p. (In Russ.).

87. Kumratova A.M., Popova E.V. Risk assessment and management: Analysis of time series by methods of nonlinear dynamics. Krasnodar: Kuban State Agrarian University; 2014. 212 p. (In Russ.).

88. Kozlov D.A. Methods of nonlinear dynamics in modeling macroeconomic processes. Nauchnye trudy: Institut narodnokhozyaistvennogo prognozirovaniya RAN = Scientific Articles: Institute of Economic Forecasting. Russian Academy of Sciences. 2003;1:157173. (In Russ.).

89. Popova E.V., Perepelitsa V.A., Komissarova K.A. Modeling the activities of insurance companies using nonlinear dynamics methods. Krasnodar: Kuban State Agrarian University; 2007. 200 p. (In Russ.).

90. Minaev A.A., Minaev G.A. Nonlinear differential equations as a characteristic of dynamic patent systems (DPS). Izobretatel'stvo. 2015;6(4):13-24. (In Russ.).

91. Minaev A.A., Minaev G.A. Foundations of the dynamic theory of innovation (patent information). Moscow: Sputnik+; 2013. 52 p. (In Russ.). 


\section{Appendix 1}

\section{Intellectual Property Analysis Methods in Papers by Foreign Authors}

Authors

Analysis problems
Analysis approaches and methods

Qualitative

Case study
Quantitative
J. de Beer, I.P. McCarthy,

A. Soliman, E. Treen

Choice of IP crowdsourcing strategy

Research and classification of the ways of interaction between commercial companies and

H. Pinto, M.P. Yruela, T.S. Pereira universities

D.J. Jefferson, M. Maida, A. Farkas,

M. Alandete-Saez, A.B. Bennett

Comparison of programs for IP management, technology transfer and entrepreneurial activities encouragement of the top American research institutes and universities

Interviewing, data

grouping and process-

ing

Comparative analysis

\section{Kalantaridis, M. Küttim, \\ M. Govind, C. Sousa}

D.M. Weckowska, J. Molas-Gallart,

P. Tang, D. Twigg,

E. Castro-Martínez,

I. Kijenska Dabrowska, D. Libaers

J. Chataway, S. Parks, E. Smith

Contraposition of patenting institutions and scientific results publication in the "closed partnership" and "open science" model

M. Bikard, K. Vakili, F. Teodoridis Assessment of efficiency of scientific work of the teams engaged in similar developments and comprising only academic staff with the teams based on collaboration with business

O. Gretsch, F. Tietze, A. Kock Evaluation of influence of the conditions which define attaching the IP rights and other standard contractual terms on effectiveness of university-business collaboration

N. van Stijn, F.J. van Rijnsoever,

M. van Veelen
Development of the concept of cooperation between universities and startups, analysis of advantages of using startups for technology transfer

\section{Comparative analysis}

Case study, expert Patent analysis

evaluations

Comparative analysis

Comparative analysis

Bibliometric, patent regression analysis

Questionnaire survey Regression analysis, correlation analysis

Interviewing, quali-

tative data systematic

analysis (INVIVO) 
Authors

Analysis problems
Analysis approaches and methods

Qualitative

Quantitative

Y. Wu, E.W. Welch, W-L Huang

Study of influence of institutional factors and scientists' human personality characteristics on universities' licensing activity and prospects of commercialisation of patented developments

N. Halilem, N. Amara

J. Olmos-Penuela, M. Mohiuddin

Study of influence of the universities' IP policy (including the issues of choosing legal regimes and distribution of profits from items use) on scientists' invention activity and entrepreneurial behaviour

S. Öcalan Özel, J. Pénin

Comparative analysis of strategies of licensing of universities' IP

Case study

Justification of the choice of patenting or publishing of scientific results followed by choosing a licensing strategy (exclusive license, non-exclusive license etc.)

T. Mets, A. Kelli, A. Mets,

T. Tiimann

Development and approbation of the activity indicators system related to creation and use of IP for assessment of its performance

G. Fernandes, E.B. Pinto,

M. Araújo, P. Magalhães,

R.J. Machado

M. Grazzi, C. Piccardo, C. Vergari Study of the relation between indicators of the amount of intellectual activity and financial indicators which characterise organisations' performance. Study of complementarity and substitutability of patents and trademarks for justification of IP management strategies

Development of a method and indicators system for quantitative measurement of performance of joint research projects and programs implemented by universities and business
Questionnaire survey Descriptive analysis, regression analysis

Questionnaire survey Regression analysis

$-$

Game theory methods

Interviewing, compar- Bibliometric, patent ative analysis analysis

Case study Bibliometric analysis

Econometric (including regression analysis) parameter analysis methods, probabilistic methods

I. Stefan, L. Bengtsson

Study of influence of the extent of readiness to enter into collaborations with various part- Questionnaire survey ners' groups on efficiency of the innovation process at different stages

Patent, regression, correlation analysis

S. Veltri, P. Puntillo Study of use of the indicators which characterise various components of universities' knowledge capital as criteria for evaluation of effectiveness of the managerial staff activity

F. Pasimeni, A. Fiorini,

Assessment of the amount of innovation activity and R\&D expenses for development of strategies in the priority technological fields

Patent analysis, mathe-

A. Georgakaki

Study of promising areas of patent analytics development. Development of a technology roadmap in order to facilitate cooperation and coordinated actions in the patent analytics experts' community

Case study, interview-

ing

L. Aristodemou, F. Tietze,

N. Athanassopoulou, T. Minshall

$-$

matical analysis methods

Desk study, question-

naire survey, expert

methods 
Authors

Analysis problems
Analysis approaches and methods

Qualitative

Quantitative

Patent analysis

Revealing the factors which define the sources of IP (development and patenting of own engineering solutions or purchase of exclusive rights) and evaluation of influence of patent purchasing deals on further patent activity (on the basis of patents quantity and quality)

\section{A. Abood, D. Feltenberger}

Development of a new method for patent landscape design aimed at simplification of the technique of patent information processing and creation of analytic representations

J.A. Smith, Z. Arshad, A. Trippe, G.S. Collins, D.A. Brindley, Content analysis and development of recommendations concerning the structure of a patent landscape report

A.J. Carr

C. Odasso, G. Scellato, E. Ughetto Analysis of influence of patent characteristic features on their market value and revealing the factors which have positive effect (number of quotes, claims of a patent etc.) on the price

Expert methods

Machine learning

Delphi method

Analysis of influence of patent characteristic features (number of backward citations), scope of legal protection, patenting geography) on dynamics of patents value change

Econometric analysis methods (including probit regression)

\begin{tabular}{ll} 
S-H. Chang, C-Y. Fan & $\begin{array}{l}\text { Analysis of influence of patent characteristic features (number of backward citations), } \\
\text { scope of legal protection, patenting geography) on dynamics of patents value change }\end{array}$ \\
\hdashline K. Jutimongkonkul & $\begin{array}{l}\text { Analysis of practice of applying the income, cost and market-based approach by IP evalu- } \\
\text { ation experts and modeling of the patent evaluation procedure }\end{array}$
\end{tabular}

L. Tahmooresnejad, C. Beaudry Study of interdependence between the patent value assessment and characteristic features of a triadic patent family

M. Grimaldi, L. Cricelli, F. Rogo Development of a technology audit methodology in order to manage the patent portfolio and develop an IP management strategy on the basis of its reconciliation with the general business strategy of an economic entity
Time series analysis, modeling

Interviewing (of -
experts)

(1)

- $\begin{aligned} & \text { Binomial regression } \\ & \text { models }\end{aligned}$

Case study, question- Coefficient method naire survey, inter-

viewing 


\section{Appendix 2}

\section{Areas and Methods of Intangible Assets Analysis in the Russian Scientists' Papers}

Authors $\quad$ Analysis areas $\quad$ Analysis methods

General methodological foundation

Bakanov M.I., Sheremet A.D. Saifulin R. S., Mel'nik M.V.

Analysis of intangible assets utilisation efficiency

Analysis of intangible assets amount, dynamics, structure

Savitskaya G.V. Analysis of intangible assets utilisation efficiency

Analysis of information and intellectual resources, technology and products as well as the client capital of business

Bulyga R.P.

Assessment and management of risks of a business based on intellectual capital

Analysis of intangible assets dynamics

Analysis of intangible assets dynamics, structure and evaluation of its change

Zhuravleva N.V.

Kremer K.I.,

L'vovich E.M.

Analysis of yield on capital investment of intangible assets

Analysis of intangible assets cost-effectiveness
Complex economic analysis (role of noncurrent assets analysis in the complex economic analysis system, complex analysis methods)

Horizontal analysis which implies calculation of absolute and relative deviations from the permanent and changing base as well as average deviations; vertical analysis in order to assess the structure of intangible assets on the basis of sources, types, usable life expectancy, degree of legal protection, prestige value, liquidity and risk of investing in immaterial goods, disposal locations and extent of utilisation for manufacture and sales

Ratio analysis (intangible assets earning power, turn-round, cost-effectiveness); discounting (calculation of economic benefit from use of licenses and know-how); factorial analysis

Horizontal analysis, vertical analysis, comparison method

Ratio analysis (intangible assets earning power, cost-effectiveness, yield on capital investment), factorial analysis of change income per one rouble of the capital invested in intangible assets

Relative indicators analysis (coefficients, indexes including the index of the corporate intellectual potential recognition, novelties turnaround, trademark popularity index)

Options method (real options, intangible options)

Horizontal analysis, absolute values, comparison method, ratio analysis

Vertical analysis, comparison method

Relative indicators analysis (coefficients), comparison method, factorial analysis, balance method

Relative indicators analysis (coefficients), comparison method, factorial analysis, balance method 


\section{Authors}

Zhuravleva N.V.

Kremer K.I.

L'vovich E.M

$\ldots$

\section{Analysis areas}

Analysis of intangible assets liquidity and degree of risk of investing in intangible assets

Analysis of influence of intangible assets utilisation efficiency on the corporate financial standing

Analysis of company's needs in intangible assets

Assessment of the value (fair) of intangible assets

Analysis of composition, structure and flow of intangible assets

Analysis of legal protection of intangible assets

Endovitskii D.A.

Isaenko A.N.,

Lubkov V.A.,

Zhuravleva N.V.,

Korobeinikova L.S.

Kretov A.A.,

Kupryushina O.M.,

Panina I.V.,

Rakhmatulina R.R.,

Silaeva Yu.A.
Predictive analysis of intangible assets supply and demand

Analysis of intangible assets turnaround and cost-effectiveness

Analysis of return on investments in intangible assets and risks related to them

Analysis of expenses for maintenance of intangible assets in working order

Revealing of the stochastic dependence between the amount of intangible assets and various factors which influence the result indicator

Analysis of evident and not evident income from intangible assets utilisation

Analysis of influence of presence and utilisation efficiency of intangible assets on the company financial standing and its market value

\section{Analysis methods}

Building of predicative models, forward financial statements, dynamic analysis models, vertical analysis, discounting, ratio analysis

Relative indicators analysis (coefficients), factorial analysis

Functional analysis, econometric and mathematical methods, stochastic analysis methods

Relative indicators analysis, ratio analysis, comparison method

Vertical analysis, comparison method, horizontal analysis, absolute values analysis, ratio analysis

Vertical analysis, discounting, econometric and mathematical methods, comparison method (with preceding period, with a plan, with industry average indicators)

Correlation-regression, predictive, functional analysis, econometric and mathematical methods

Relative indicators analysis (coefficients), comparison method, factorial analysis, balance method

Predicative models construction, drawing up of forward financial statements; dynamic analysis model construction; vertical analysis; discounting; ratio analysis

Forward financial statements, dynamic analysis models, vertical analysis, discounting, ratio analysis, simmple and compound interest method

Correlation-regression analysis (model of dependence of the intangible assets amount on various values of the financial ratios series)

Relative indicators analysis (coefficients), comparison method, factorial analysis, balance method, calculation of the intangible asset actual efficiency

Relative indicators analysis (coefficients), comparison method, factorial analysis, econometric and mathematical methods, simulation modeling, calculation of absolute and average values 
Ratio analysis (analytical indicators of innovation, competitive, marketing, investment analysis, in total 24 ratios); non-formalised (logical) methods (Delphi method, scenario method, psychological methods, morphological methods, comparison methods, construction of analysis schedules); elementary methods of microeconomic analysis (factorial analysis methods, differential analysis, logarithmic analysis, integral analysis); conventional methods of economic statistics (average values method, grouping method, time series processing methods, index method);

Integrated managerial analysis of the entity innovative

Ilysheva N.N., activity

Krylov S.I.

Mikhailov O.V. mathematical and statistical methods (correlation analysis, regression analysis, variance analysis, cluster analysis, time-space population processing methods); decision-making theory methods (case study and forecasting methods, simulation modeling, decision tree derivation method, linear programming, sensitivity analysis); financial computing methods (discounting and increment, cashflow analysis)

Analysis of reputation (goodwill)
Analysis of IP as a factor of earning power regulation

Calculation method of profitability rate of the goodwill created by the company

Factorial analysis, correlation and regression analysis

Complex analysis of intangible assets utilisation (analysis

Prokop'eva Yu.V. of the structure, state, flow, investment analysis, integrated assessment of intangible assets utilisation efficiency)

Ratio analysis, factorial analysis (factor model of labour productivity on the basis of return on of return on intangible assets)

Analysis of risks, uncertainty, solutions and models of

Gusev V.B., Guseva intangible assets management

N.E., Isaeva N.A.

Analysis of influence of intangible assets on synergistic effect of the company operations

Reflexive analysis method, expert analysis

Method of synergistic effect evaluation using the equilibrium growth indicator, optimisation methods

Analysis of the amount and dynamics of intangible assets Horizontal analysis, absolute and relative indicators, ratio method

Mistyukova I.P.,

Ryabchenko T.N.

and Furmanova N.V.

.

Analysis of intangible assets structure

Vertical analysis (on the basis of sources, reasons for disposal etc.)

Analysis of return on and capacity of intangible assets

Ratio method, factorial analysis (of return on intangible assets)

Analysis of profitability (cost-effectiveness) of intangible assets utilisation

Ratio method, factorial analysis (of individual profitability of each IP item) 
Authors Analysis areas

Analysis of structure and dynamics of license and fran-

Analysis of income and expenditure from making indus-

Krivitskaya K.V. chising agreements trial intangible assets available for use

Analysis of financial results of making industrial intangi-

ble assets available for use

\section{Analysis methods}

Horizontal analysis of contracts in monetary terms, vertical analysis of concluded contracts according to areas of making the assets available for use, types of the assets made available for use, validity terms of the contracts, ratio analysis (indicators of the rate of concluding contracts of making intangible assets available for use)

Discounting (of royalty, punitive damages, service payments and the total income of the rightsholder organisation defined as the sum of income earned as a result of making the assets available for use and the income earned additionally from use in the organisation's own operations)

Analysis of absolute indicators of financial results from making industry intangible assets available for use depending on the type of organisation (rightsholder and usufructuary) and the type of use (making available for use, getting for use, utilisation in one's activities and making available for use by third parties); ratio analysis (of cost-effectiveness), revealing reserves for income growth of the rightsholder organisation and licensee organisation
Plaskova N.S.,

Prodanova N.A.

Assessment of effectiveness of the company innovation activity
Polyanskaya T.A.

Qualitative methods, factorial analysis, investment design, assessment of growth reserves of innovation activity expansion

Mathematical apparatus of the game theory, in particular, finding situations of Stackelberg equilibrium in the analysis of a three-dimensional restrictive model of patent protection and defining:

Assessment of the synergistic economic effect from pat- $\quad$ - the economic benefit of the patent height which defines the minimum number of new eleent exploitation

ments which the invention improvement should contain;

- the economic benefit of the patent width which defines the maximum permissible number of elements of a patented subject which may be imitated;

- the synergistic economic effect of the patent height and width.

Managerial analysis of intellectual assets

System of relative analytical indicators and indexes of efficiency evaluation of corporate intellectual assets offered for use within the model of nodal structure of intellectual assets management accounting

Comparison method (current data - to similar data of the previous period, current data - to budget and forecast data, current indicators - to their regulatory values, current indicators to industry average indicators, financial ratios - to non-financial indicators); ratio method; balance method (preparing a comparative analytical balance sheet) 


\section{Appendix 3}

\section{Objectives and Tools of Patent Analytics at the Macro- and Microlevel}

\begin{tabular}{|c|c|c|c|}
\hline Analysis level & Analysis problems & Patent analytics tools & Sources/authors \\
\hline \multirow{4}{*}{ Macro } & $\begin{array}{l}\text { Study and forecasting of scientific and technical develop- } \\
\text { ment (of an industry, region, country), revealing the top } \\
\text { global development centers, owners of the most valuable } \\
\text { technology, forecasting of introduction of new technolo- } \\
\text { gy in the markets }\end{array}$ & $\begin{array}{l}\text { Preparing industry-specific and express } \\
\text { patent landscape reports }\end{array}$ & $\begin{array}{l}\text { Guidelines for Preparing Patent Landscape Reports } \\
\text { (WIPO) } \\
\text { A. Abood, D. Feltenberger, } 2018 \\
\text { J.A. Smith, Z. Arshad, A. Trippe, G.S. Collins, D.A. Brin- } \\
\text { dley, A.J. Carr, } 2018\end{array}$ \\
\hline & $\begin{array}{l}\text { Assessment of the probability of obtaining a protection } \\
\text { document for an intellectual product in one or more } \\
\text { countries }\end{array}$ & Patentability assessment & $\begin{array}{l}\text { GOST R 15.011-96 } \\
\text { L. Aristodemou, F. Tietze, N. Athanassopoulou, T. Min- } \\
\text { shall, } 2017\end{array}$ \\
\hline & $\begin{array}{l}\text { Assessment of the probability of use of a technological } \\
\text { item in any country in compliance with the exclusive } \\
\text { rights in force in its territory to the IP items which be- } \\
\text { long to third parties }\end{array}$ & Examination for patent purity & $\begin{array}{l}\text { V.V. Shvedova, } 2015 \\
\text { L. Aristodemou, F. Tietze, N. Athanassopoulou, T. Min- } \\
\text { shall, } 2017\end{array}$ \\
\hline & $\begin{array}{l}\text { Study and cataloguing of modern technology, products } \\
\text { and leading companies followed by analysis of the pat- } \\
\text { ents protecting the selected products and technology }\end{array}$ & Patent technology scouting & $\begin{array}{l}\text { F. Pasimeni, A. Fiorini, Georgakaki, } 2019 \\
\text { S.Y. Kim, H.J. Lee, } 2019\end{array}$ \\
\hline \multirow{3}{*}{ Micro } & $\begin{array}{l}\text { Evaluation of importance/quality of patents, finding } \\
\text { engineering solutions which have commercial potential }\end{array}$ & Technology assessment or technology audit & $\begin{array}{l}\text { V.A. Antonets, N.V. Nechaeva, K.A. Khomkin, V.V. } \\
\text { Shvedova, } 2009 \\
\text { V.V. Kerimov, } 2014 \\
\text { M. Grimaldi, L. Cricelli, F. Rogo, } 2018 \text { S.Y. Kim, H.J. } \\
\text { Lee, } 2019\end{array}$ \\
\hline & \multirow{2}{*}{$\begin{array}{l}\text { Monetary estimate of IP items for the purpose of ac- } \\
\text { counting and management }\end{array}$} & $\begin{array}{l}\text { Ratio method taking into consideration } \\
\text { patent research results }\end{array}$ & $\begin{array}{l}\text { E.P. Skornyakov, N.M. Tsekhmistrenko, M.E. Gorbuno- } \\
\text { va, } 2008 \\
\text { E.P. Skornyakov, M.E. Gorbunova, } 2011\end{array}$ \\
\hline & & $\begin{array}{l}\text { Analysis of influence of patent characteristic } \\
\text { features on their monetary estimate }\end{array}$ & $\begin{array}{l}\text { C. Odasso, G. Scellato, E. Ughetto, } 2015 \\
\text { S-H. Chang, C-Y. Fan, } 2017 \\
\text { L. Tahmooresnejad, C. Beaudry, } 2019\end{array}$ \\
\hline
\end{tabular}




\section{Appendix 4}

\section{Methods of Transparency Analysis of Public Sector Entities}

Authors

Analysis problems

Revealing redundant parameters showing a strong correlation with other variables in order to exclude them

Establishing a mathematical relation between reporting indicators

I.M. Welpe,

J. Wollersheim,

S. Ringelhan,

M. Osterloh

Revealing of hidden variable factors determining presence of linear statistical correlations between the observed variables

Defining the "efficient frontier", estimation of efficiency of the analysed item, its individual structural units, their grading according to efficiency level and forecasting of inefficiency states

Defining the most probable scenarios of prospective changes of the analysed item, drawing up recommendations for management decision making

Evaluation of the amount of information disclosed in the statutory and voluntary reporting

Assessment of the relative disclosure level

Revealing disclosure determinants

Systematising of the information disclosed in reports which is mainly of descriptive character according to three levels: essential, desirable and optional

J. Denoncourt

T. Peters, J. Thiel,

C.L. Tucci

Evaluation of the possibility of improvement and use of competitive advantages by means of disclosing information on inventions for efficient strategies development

Analysis of compliance of the information actually disclosed in reporting with the International Financial Reporting Standards as regards accounting of intangible assets and analysis of interrelation of the disclosure extent and the company market value

P. André, D. Dionysiou, I. Tsalavoutas

Analysis of compliance of the information actually disclosed in reporting with the International Finan-

A. Devalle, F. Rizzato,

D. Busso cial Reporting Standards as regards accounting of intangible assets and analysis of influence of various factors (size, business legal structure, industry sector etc.) on the extent of disclosure

Analysis methods

Correlation analysis

Regression analysis

Factorial analysis

Non-parametric and parametric methods of the frontier analysis

Expert system on the basis of fuzzy logic

Content analysis

Disclosure index

Regression analysis

Three-level model of IP and patent strategy disclosure

Case study

Index method, regression analysis

Index method, regression analysis 
J.S. Gans, F.E. Murray,

S. Stern

Comparative analysis of four strategies of engineering solutions disclosure: secrecy, patenting, scientific paper, combination of patenting and publishing a paper. Development of a theoretical model for the strategy choice justification.

A. Maaloul,

W.B. Amar, D. Zeghal

Analysis of influence of the extent of intangible assets disclosure (including elements of human, intellectual and relational capital) on analysts' forecasts of the company profitability

F. Schiemann, Study of the relation between the intangible assets information disclosed in the accounting (financial)

K. Richter, T. Gunther and voluntarily disclosed information on intellectual capital

Study of the structure and contents of the Management Comments to the reports prepared in accor-

P. Catalfo, I. Wulf dance with IFRS in Germany and Italy in order to assess the possibility of satisfying needs of concerned parties in the information which has been disclosed insufficiently in the reports using the data stated in the Management Comments

S. Fontana

Study of influence of various factors on the disclosure level, herewith the value added intellectual coeffi-

D. Coluccia cient (VAIC) and monetary estimate of intangible assets are considered as the factors

\section{Modeling}

Correlation and multivariate regression analysis

Regression analysis

Semantic analysis, content analysis

Stakeholder approach, index method, regression analysis, statistical modelling 